УДК 591.9 (4-013). 598.2./9

\title{
ПРОСТРАНСТВЕННО-ТИПОЛОГИЧЕСКАЯ СТРУКТУРА И ОРГАНИЗАЦИЯ НАСЕЛЕНИЯ ПТИЦ ТОБОЛО-ИРТЫШСКОЙ ЛЕСОСТЕПИ И СТЕПИ ЗАПАДНОЙ СИБИРИ И СЕВЕРНОГО КАЗАХСТАНА ВО ВТОРОЙ ПОЛОВИНЕ ЛЕТА
}

\author{
Соловьев С. А., Вартапетов Л. Г. \\ ФГБУН Институт систематики и экологии жсивотных СО РАН, г. Новосибирск \\ E-mail: solov_sa@mail.ru
}

\begin{abstract}
По результатам учетов птиц, проведенных в 138 местообитаниях за 12 лет, в период с 1982 по 2002 г. составлены иерархическая классификация и структурный граф сходства орнитокомплексов равнинной юго-западной части Западной Сибири и Северного Казахстана. Иерархическая классификация содержит 6 типов населения птиц. Граф сходства построен на уровне типов и представлен тремя рядами (трендами). Один ряд состоит из орнитокомплексов селитебных и рекреационных территорий, второй - из водно-болотных угодий и третий - из лесных, лесополевых и степных местообитаний. Приведенные характеристики таксонов классификаций содержат информацию по трем наиболее многочисленным видам птиц (лидерам по обилию), их доле в сообществе, плотности населения, а также по фоновому видовому богатству. На основе оценки степени совпадения сходства орнитокомплексов и факторов среды установлена иерархия воздействия основных антропогенных и природных факторов, определяющих формирование населения птиц.
\end{abstract}

Ключевые слова: птицы, орнитокомплексы, кластерный анализ, факторы среды, корреляция.

DOI: 10.34078/1814-0998-2021-4-51-60

\section{ВВЕДЕНИЕ}

Летнее население птиц равнинной югозападной части Западной Сибири и Северного Казахстана остается мало изученным (Соловьев, 2012). Эта территория испытывает постоянное воздействие развития аграрных и селитебных ландшафтов и, с большой вероятностью, климатических изменений. По имеющемуся прогнозу (Павлов, Гравис, 2000), южная граница многолетней мерзлоты в Сибири (а значит, и южнее расположенных природных зон) уже в середине XXI в. может сместиться до 600 км к северу. Возможная аридизация может вызвать опустынивание на юге рассматриваемой территории и дальнейшее обезлесение на ее севере. Поэтому столь необходимо зафиксировать современное экологическое состояние орнитокомплексов именно на юге Западной Сибири, чтобы оценить происходящие и возможные здесь изменения экосистем. Выполненная нами и подобные ей количественные оценки населения птиц, в том числе построенные на ландшафтной основе, служат для развития международных систем орнитологического мониторинга, в основном нацеленных на выявление популяционных трендов гнездящихся

(C) Соловьев С. А., Вартапетов Л. Г., 2021 и мигрирующих птиц (Gregory, 2000; Svensson, 2000; Sanderson et al., 2006; Gregory et al., 2007). В России ландшафтно-типологический подход в орнитологическом мониторинге направлен на решение общих задач экологического мониторинга, а также сохранения и восстановления биологических ресурсов и биоразнообразия (Гармаев и др., 2016).

Цель статьи, предлагаемой вниманию читателей, сводится к обобщенному анализу орнитокомплексов. Основные задачи: выявить природные и антропогенные факторы, определяющие формирование населения птиц лесостепи и степи юго-западной части Западной Сибири и Северного Казахстана; оценить изменения в населении птиц в послегнездовой период по сравнению с гнездовым; установить региональную и зональную специфику орнитокомплексов.

\section{МАТЕРИАЛ И МЕТОДЫ}

Для анализа структуры и организации населения птиц исследуемого региона использованы данные по численности птиц, собранные в период их учетов в 1986-1988 и 1997 г. в южной лесостепи, в том числе в г. Омск и его окрестностях. В северной лесостепи Прииртышья учеты птиц автором выполнены в 1998-2001 и 
в 1999, 2002 г. Также привлечены опубликованные данные Т. К. Блиновой и В. Н. Блинова по лесостепи Притоболья в 1982-1984 гг. и северной степи Тургайской меридиональной депрессии в 1986 г. Всего для характеристики населения птиц Тоболо-Иртышской лесостепи и степи Западной Сибири и Северного Казахстана использованы данные по 138 местообитаниям птиц во второй половине лета (послегнездовой период).

Методика учета птиц подробно изложена в публикации Ю. С. Равкина и С. Г. Ливанова (2008). Для обобщения информации о территориальной неоднородности орнитокомплексов, а также для выявления основных структурообразующих факторов среды в работе применены нелинейные методы многомерной статистики, в том числе кластерный анализ. При описании пространственно-типологической структуры населения птиц использованы результаты анализа графа, построенные на основе коэффициентов сходства Жаккара - Наумова (для количественных признаков). Структурные графы иллюстрируют смену сообществ по биотопам, позволяют выявлять основные тренды (длительные, а не только локальные изменения) по значимым связям и представляют собой модификацию иерархических классификаций с учетом не только внутригруппового сходства сообществ, но и их межгрупповой близости. Результаты классификации всей совокупности сообществ после одной или двух повторных агрегаций считали делением на типы населения. Эти методы способствуют формированию более представительного, необходимого и достаточного для описания набора структурообразующих факторов среды и их неразличимых сочетаний (природных режимов). Для оценки силы связи между неоднородностью орнитокомплексов и коррелирующими с ней факторами применена линейная качественная аппроксимация матриц связи (один из методов регрессионного анализа) (Равкин, Ливанов, 2008). Множественная оценка силы связи всех факторов и режимов с территориальной неоднородностью сообществ птиц позволяет судить о степени информативности излагаемых представлений и о скоррелированности действия факторов между собой.

Видовые названия птиц приводятся по Л. С. Степаняну (2003). Обработка материалов и все основные расчеты проведены с использованием программ лаборатории зоологического мониторинга Института систематики и экологии животных (ИСиЭЖ СО РАН, Новосибирск). В учетах птиц в 12 местообитаниях Прииртышья летом 1987 г. участвовал К. В. Торопов, за что авторы выражают ему глубокую признательность.

\section{РЕЗУЛЬТАТЫ И ОБСУЖДЕНИЕ}

Во второй половине лета (в послегнездовой период) пространственно-типологическая структура населения птиц Тоболо-Иртышской лесостепи и степи принципиально сходна с таковой для первой половины лета (Соловьев, Вартапетов, 2021), когда также выделены три системы орнитокомплексов (см. рисунок). В целом же она приобретает несколько иной характер, определяемый интенсивными послегнездовыми кочевками и миграциями птиц из лесной зоны, а также повсеместной дисперсией синантропных видов. Это приводит к появлению в верхней части графа двух горизонтальных рядов отклонения от основного вертикального ряда, что определяется в основном застроенностью, рудеральностью и антропогенной кормностью местообитаний.

Первая система орнитокомплексов в левой части схемы также образует население птиц незастроенной суши и представляет собой вертикальный ряд структурного графа (1-5-й подтипы). Территориальная изменчивость населения птиц определяется снижением облесенности и возрастанием распашки. Как и в первой половине лета (Соловьев, Вартапетов, 2021), в списке лидеров колочных лесов с полями и лугами (1-й подтип) отмечен лесной конек. Однако из списка исчезают зяблик и серая славка и появляются прикочевавшие большая синица и буроголовая гаичка. Второй подтип ряда (парков и промышленнотехногенных территорий городов и пригородов) определен интенсивной послегнездовой прикочевкой полевого воробья, сороки и желтой трясогузки.

Сообщества птиц парков и промышленных зон оказываются наиболее сходными с таковыми новых пойменных парков долины Иртыша (3-й подтип). Этим орнитокомплексам также свойственна существенная послегнездовая прикочевка наиболее многочисленных видов: желтой трясогузки, барсучка и бекаса, которые заменили лидеров первой половины лета (сороку, грача и полевого жаворонка). В лугах лесостепи и на открытых участках степных ландшафтов в значительном количестве появился скворец, заменивший желтую трясогузку. Лугово-степной подтип (4-й) по-прежнему характеризуется высоким обилием полевого жаворонка и грача, как и в первой половине лета. Этот подтип по вертикальному ряду достаточно сильно (14 ед.) связан с 5-м лугово-полевым подтипом, лидерами которого отмечен полевой воробей, а также лесополевые и степные виды (грач и полевой жаворонок). В первой половине лета состав доминантов здесь был совершенно иной: желтая трясогузка, серая ворона и чибис. Ряд сообществ застроенных местообитаний становится более дифференцированным, чем в первой половине лета. 


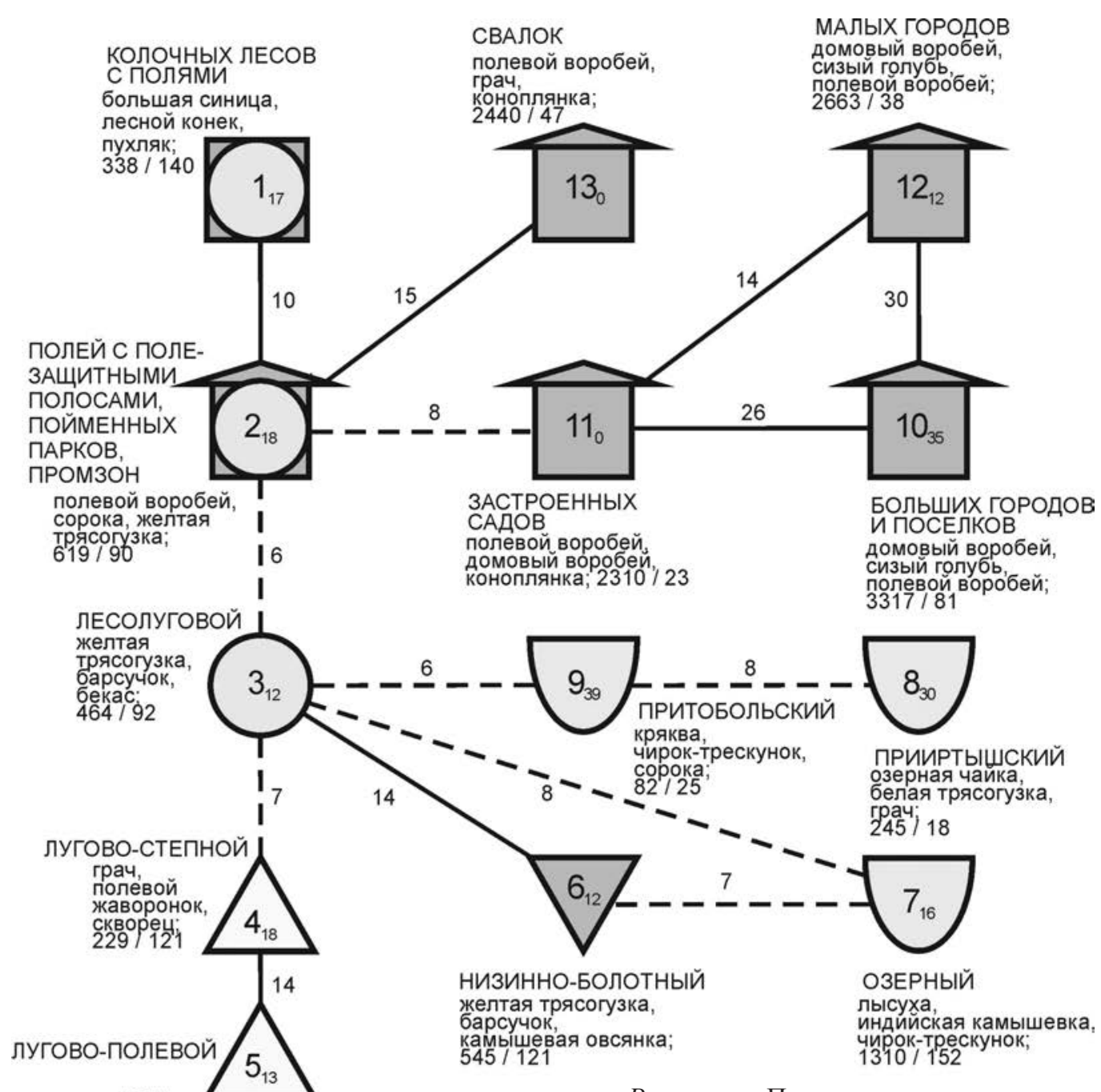

прач, пой жаворонок полевой жаворонок $138 / 106$

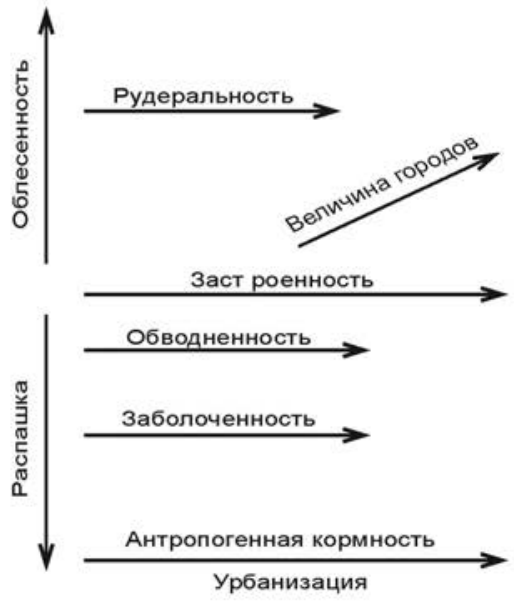

Рисунок. Пространственно-типологическая структура населения птиц лесостепи и степи Западной Сибири и Северного Казахстана во второй половине лета. Орнитокомплексы: 1 - лесополевых, 2 - частично облесенных местообитаний, 3 - полей, 4 - лугов, низинных болот, 5 - селитебных и техногенно-рудеральных территорий, 6 - водоемов и водотоков. Цифрами обознаены номера типов, индексы - величина внутритипового сходства. Сходство классов изображено примерно в обратном масштабе (чем больше сходство между классами, тем меньше расстояние). Цифры в кружках, прямоугольниках и т. п. - номера типов, индексы величины внутриклассового сходства. Сплошные линии означают сильное сходство. Для каждого типа указаны виды-лидеры (в среднем по вошедшим в них вариантам населения птиц). Стрелки - основные направления изменений сообществ и факторов среды

Figure. Spatial-typological structure of the bird population in the forest-steppe and steppe of Western Siberia and Northern Kazakhstan in the second half of summer. Ornithocomplexes: 1 - forest-field, 2 - partially forested habitats, 3 - fields, 4 - meadows, lowland swamps, 5 - residential and technogenic ruderal areas, 6 - reservoirs and watercourses. Numbers are types; indices, values of intra-type similarity. Class similarity is depicted approximately in the opposite scale (the greater the similarity between the classes, the smaller the distance). Numbers in circles, in rectangles, etc. indicate type numbers; indices are values of intra-class similarity. Solid lines show strong resemblance. For each type, the leader species are indicated (on average, according to the variants of the bird population included in them). Arrows show the main directions of changes in communities and environmental factors 
Это происходит за счет возрастания численности антропофильных и антропотолерантных птиц после их размножения с началом интенсивных послегнездовых кочевок и миграций из лесной зоны и тундры (10-12-й подтипы). Единственное отклонение от этого ряда представлено населением птиц свалок (13-й подтип), который за счет интенсивной прикочевки полевого воробья, грача и коноплянки приобретает промежуточный облик между застроенными и незастроенными местообитаниями суши. Тип населения птиц болот, водоемов и водотоков (6-9-й подтипы) попрежнему обособлен. Это вызвано концентрацией в тростниковых полузатопленных зарослях озер и по их берегам лысухи, чирка-трескунка и индийской камышевки. На закустаренных берегах Тобола держатся сорока, а на воде - кряква, чироктрескунок. На более антропогенно трансформированных и открытых реках Прииртышья (Иртыше и Оми) лидируют озерная чайка, белая трясогузка и грач, а в низинно-болотном 6-м типе - желтая трясогузка, барсучок и камышевая овсянка. Эта овсянка, появившаяся в значительном количестве, замещает здесь индийскую камышевку.

Таким образом, во второй половине лета выявленные типы структурного графа заполняют факторное пространство более равномерно и упорядоченно, чем в первой половине, в связи с выравнивающим влиянием послегнездовых перемещений птиц, но граф оказывается менее компактным (переходы от одной группы сообществ к другой часто не накладываются на проявление основных трендов, делая структурный граф менее генерализованным). Это наиболее характерно для вертикального ряда от населения колочных лесов к лугово-полевым местообитаниям, изменение в котором обусловлено снижением облесенности и возрастанием сельскохозяйственной трансформации ландшафтов. Особенно заметно проявляется на облике населения луговополевого подтипа с грачом, полевым жаворонком и полевым воробьем в качестве лидирующих по обилию видов. При этом виды-лидеры, характерные для первой половины лета, остаются таковыми и для второй половины. Однако в лесополевых ландшафтах появившаяся большая синица сменяет лесного конька и буроголовую гаичку, а в парковые биотопы из селитебных участков прикочевывает полевой воробей, а также из лесолуговых и лугово-степных местообитаний расселяются сорока и желтая трясогузка. Она вместе с барсучком и бекасом лидирует в лесолуговом типе, заменив гнездившихся там и откочевавших сороку и полевого воробья. Список лидеров лугово-степного типа остается прежним, лишь во второй половине лета исчезает желтая трясогузка и ее заменяет скворец. На селитебной территории лидеры прежние для жилой части горо- дов и поселков (домовый воробей, сизый голубь, полевой воробей). В застроенных садах лидируют полевой и домовый воробьи, а также коноплянка. С территории свалок исчезают скворец и сизая чайка, но по-прежнему лидирует грач, дополненный полевым воробьем и коноплянкой. В подтипе рек, озер и болот летом состав лидеров наиболее стабилен. Так, с закустаренных берегов Тобола откочевала серая ворона, а появилась кряква; с берегов Иртыша и Оми откочевал полевой воробей, и лидирует белая трясогузка. На озерах красноголового нырка замещает чирок-трескунок, а индийскую камышевку на болотах сменяет пролетная камышевая овсянка. Исчезновение видов, определявших сходство населения выделенных типов в первой половине лета, совпадает с отлетом части или всех отгнездившихся птиц. Появление в списке эдификаторов новых видов связано с началом их массовых послегнездовых кочевок.

Для провинции лесостепи Обь-Иртышского междуречья и долины Оби, граничащей на востоке с исследуемой нами территорией, также установлено, что пространственная неоднородность летнего населения птиц обусловлена облесенностью, обводненностью и застроенностью территории. На орнитокомплексы болот и водоемов значительное воздействие также оказывает наличие или отсутствие мощных зарослей тростника. Подзональные отличия, как и в нашем случае, менее значимы для структуры летнего населения птиц, а рельеф в сочетании с увлажнением и богатством минерального питания фитоценозов сильнее воздействует на изменчивость сообществ лесостепи Приобья (Торопов и др., 1985). Отличие структурных графов обследованной нами центральной части лесостепи и степи обусловлено значительно большей антропогенной трансформацией местообитаний, что также отмечено и для орнитокомплексов лесостепи Средней Сибири (Жуков, 2006).

В целом значительная антропогенная трансформация местообитаний Тоболо-Иртышской лесостепи, степи Западной Сибири и Северного Казахстана, техногенных ландшафтов Южного Прибайкалья и лесостепи Средней Сибири определяет сходство факторов, обусловливающих территориальную неоднородность населения птиц во второй половине лета. Отличия в их наборе, как и в первой половине лета, определяются более широким спектром антропогенных воздействий; в нашем случае они объединены как антропогенная кормность, рудеральность, застроенность, величина городов и распашка. В. С. Жуков (2006) для лесостепи Назаровской котловины классифицировал их только как распашку и буроугольные разработки, В. О. Саловаров - как техногенное воздействие. По срав- 
нению с пространственно-типологическими структурами населения птиц менее нарушенных ландшафтов Западной и Средней Сибири прослеживается сходство в факторах, определяющих территориальную неоднородность населения птиц во второй половине лета. Так, смена орнитокомплексов Ханты-Мансийского автономного округа, техногенных ландшафтов Южного Прибайкалья, а также лесостепи и степи нашего региона определяется сходными факторами, за исключением техногенного воздействия в Южном Прибайкалье, а в нашем случае антропогенной кормности, распашки, рудеральности и величины городов. Кроме того, в северной тайге выделяются тренды по продуктивности и рельефу. Отсутствие их в нашем анализе связано с более значимым сельскохозяйственным и урбанизированным воздействием (в виде антропогенной кормности), которые становятся основными фактороми, определяющими изменения населения птиц региона.

Ранее было установлено, что при значительных площадях обследованных природных зон Западной Сибири в целом в качестве основных факторов, определяющих смену сообществ птиц и мелких млекопитающих, приняты зональность и теплообеспеченность, которые не выявлены на нашем графе. Это еще раз подчеркивает превалирующее влияние сельскохозяйственной и селитебной нагрузки на лесостепные и степные ландшафты юго-западной части Западной Сибири и Северного Казахстана, что совершенно размывает ландшафтногеографические границы между исследуемыми природными зонами. Это связано со значительной, местами практически тотальной распашкой и застройкой территории лесостепи и степи около крупных областных и районных центров, а также почти полностью выбитыми выпасами близ всех населенных пунктов.

При сравнении полученной нами структуры с таковой для территории Алтая во второй половине лета, как и в первой, проявляется различие, связанное с определяющим влиянием для горных ландшафтов абсолютной высоты, которая наиболее значима для территориальной неоднородности населения птиц, только лишь в облесенных выделах. В исследуемом нами регионе антропогенная нагрузка на местообитания лесополевых и сосново-боровых ландшафтов обусловливает появление самостоятельного тренда по распашке, диаметрально противоположного направлению облесенности, как бы уравновешивая последний, что еще раз подчеркивает ее важность для формирования облика населения птиц. Отдельный тренд отклонения проявляется для застроенности и рудеральности, что ранее было установлено для большинства естественных ландшафтов Западной Сибири (Вартапетов, 1984; Равкин, 1984; Цыбулин, 1999).

При сравнении пространственно-типологической структуры населения птиц с таковой для северной тайги Западной Сибири прослеживаются отличия в выделении факторов, определяющих смену сообществ, связанных с их меньшей нарушенностью (Вартапетов, 1998). Все же это можно определить как сходное по нашему ряду возрастание облесенности от лесолуговых пастбищных и покосных выделов к более нарушенному классу полей с полезащитными полосами, городских промзон нефтезавода и пойменных парков. При этом не проявились отдельные подтипы сообществ птиц техногенных участков, которые ранее выделялись на слабо измененных территориях (Равкин и др., 1994). Выделение в нашем случае свалочного подтипа связано с повышенной кормностью свалок, в том числе за счет запасов семян рудеральных растений. Во второй половине лета также отмечено большее, чем в первой половине, сходство селитебных местообитаний со слабо измененными выделами, что приводит к их объединению в общий подтип полей с полезащитными полосами, пойменных парков и промышленных территорий нефтезавода. В сравнении с пространственно-типологической структурой населения птиц лесной зоны Западной и Средней Сибири в нашем случае во второй половине лета отмечена дифференциация антропогеннотрансформированных местообитаний от естественных ландшафтов, что в лесной зоне не проявлялось в результате выравнивающего влияния послегнездовых кочевок птиц (Равкин, 1984). Сходные тенденции формирования населения птиц прослежены и для ландшафтов Среднего Урала, где во второй половине лета вообще не проявилось промышленное воздействие. С. Г. Ливанов объясняет это возрастанием толерантности у многих птиц к облику ландшафта во время кочевок и пролета. В нашем случае послегнездовая дисперсия синантропных видов, а также концентрация пролетных и кочующих лесополевых птиц в городах, поселках и их окрестностях обусловливает появление в структуре широкого набора селитебных подтипов населения птиц.

В итоге сезонные отличия структуры населения птиц обследованной территории связаны с послегнездовой дисперсией синантропных видов и началом позднелетних миграций птиц, которые проявляются в некотором возрастании антропогенного воздействия в виде повышенной кормности урбанизированных и сельскохозяйственных урочищ. При этом для слабо изменен- 
ных и естественных ландшафтов по-прежнему наиболее значимо влияние распашки и жнивья агроценозов, а для селитебных местообитаний антропогенной кормности, что определяет формирование гораздо большего набора подтипов населения птиц структурного графа. Наряду с этим облесенность, обводненность, заболоченность сохраняют свою значимость.

Таким образом, основные территориальные изменения населения птиц Тоболо-Иртышской лесостепи и степи в первой и второй половине лета сходны и связаны с антропогенной кормностью, облесенностью, увлажненностью, закустаренностью и обводненностью местообитаний. При этом значение облесенности (в виде макрооблесенности) выражено гораздо слабее, чем в целом по северной лесостепи Западной и Средней Сибири, лесостепи Обь-Иртышского междуречья и долины Оби (Жуков и др., 1985; Торопов и др., 1985), а также в лесной зоне Западной Сибири (Равкин, 1978, 1984; Вартапетов, 1984). Это объясняется большей антропогенной трансформацией ландшафтов, что так же, как в лесостепи Средней Сибири (Жуков, 2006) и в техногенных ландшафтах Южного Прибайкалья (Саловаров, Кузнецова, 2005), значительно искажает и ослабляет влияние ряда природных факторов, в том числе и макрооблесенности. Большое влияние на облик населения в послегнездовой период оказывает расселение молодых и кочевки синантропных видов, обилие которых значительно сближает парковые местообитания с селитебной территорией, но существенно различает застроенные и свалочные участки с естественными ландшафтами. Особенность лесостепи и степи нашего региона проявляется еще и в уменьшении различий в населении птиц городских и пригородных водоемов, за исключением вариантов населения городской бетонированной набережной Иртыша, где преобладают синантропы.

Мы дифференцировали факторы среды по генезису на две группы.

Оценка силы и общности связи факторов среды с неоднородностью населения птиц Тоболо-Иртышской лесостепи и степи во второй половине лета, \% учтенной дисперсии матрицы коэффициентов сходства

Assessment of strength and generality of the relationship among environmental factors with the heterogeneity of the bird population of the Tobol-Irtysh forest-steppe and steppe in the second half of summer, \% calculated variance of the similarity coefficient matrix

\section{Фактор, режим}

Естественные

В том числе:

облесенность

преобладающий породный состав облесенных участков

обводненность

проточность

провинциальность

зональность

рельеф

кормность или трофическая ценность урочищ

Антропогенные

В том числе:

застроенность

распашка

макроурбанизация (антропогенно повышенная кормность

и озелененность селитебных местообитаний)

Все факторы

По классификации

По структуре

Всего режимы

Факторы и режимы

Коэффициент множественной корреляции
Объясненная дисперсия, \%

II половина лета (16 июля - 31 августа)

38

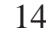

10

12

8

2

0.9

2

12 
В первую группу вошли естественные факторы. Наиболее важен фактор облесенности $(12 \%)$, значима кормность (трофическая ценность урочищ) и обводненность (12 и $10 \%$ ) и древесный породный состав облесенных участков $(10 \%)$. Ранее определено, что облесенность - наиболее существенный фактор, определяющий формирование орнитокомплексов всей лесной зоны Западной Сибири (Равкин, $1978,1984)$. Для северной тайги Западной Сибири установлено более значимое влияние состава преобладающих древесных пород. Для исследуемой нами юго-западной части Западной Сибири этот фактор тоже существенен, но более значимым, чем в северной тайге, оказался фактор обводненности территории. Это во многом обусловливает распределение орнитокомплексов в озерной лесостепи, особенно в северной части, наиболее богатой озерами. Тем не менее на фоне воздействия послегнездовых кочевок и предотлетных миграций птиц во второй половине лета состав преобладающих пород лесных участков становится не менее значим для облика орнитокомплексов, чем обводненность для линяющих здесь и пролетных северных птиц (10 и 12 \%). Значимость кормности или трофической ценности для номадов в это время несколько снижается (12\%).

В результате проведенного анализа мы можем констатировать, что тезисы Л. С. Берга о том, что «лесостепь - это область, переходная между лесом на севере и степью на юге» (Берг, 1938. C. 62), что «степи есть явление зональное, представляя промежуточный член между лесной и пустынной зоной, и, как таковые, вызваны причинами климатическими: зональным распределением климатических областей» (Берг, 1938. C. 94), не равнозначны. В конце XX и начале XXI столетия по облику населении птиц Тоболо-Иртышской лесостепи и степи верно второе утверждение Л. С. Берга: исследуемый регион, единая природная зона, в нашем понимании - степной зонобиом, включающий в себя лесостепь. В первой половине лета такими факторами, как провинциальность и зональность, объяснялось всего по 3 \% дисперсии, что определяется повсеместной антропогенной (агроселитебно-техногенной) трансформацией региона за вековой период. Тем не менее вся группа естественных факторов наиболее значима по силе и общности влияния на летние орнитокомплексы исследуемой нами лесостепи и степи, а совместное влияние всех антропогенных факторов оказалось несколько ниже. В первой и второй половине лета в нашем регионе по индивидуальной оценке наиболее значимы по сравнению со всеми остальными природными и антропогенными факторами оказались макроурбанизация (22 и 19 \% соответственно), проявляющаяся в антропогенно повышенной кормности и озелененности, а также застройка (21 и $18 \%)$ и распашка территории (4 и $3 \%$ ). Всеми перечисленными факторами и их сочетаниями (природными режимами) в первой и второй половине лета объясняется 57 и $58 \%$ дисперсии населения птиц.

Такая иерархия влияния основных факторов среды для организации населения птиц ТоболоИртышской лесостепи и степи, как и для преимущественно техногенных ландшафтов Южного Прибайкалья (Саловаров, Кузнецова, 2005), существенно отличается от таковых в менее трансформированных ландшафтах лесной зоны Западной Сибири и гор Южной Сибири. Так, например, ранее установлено, что при индивидуальной оценке изменчивости населения птиц лесной зоны Западной и Средней Сибири и определяющих ее факторов среды в первой половине лета наиболее значимой является степень залесенности, которой определяется $61 \%$ дисперсии орнитокомлексов. Втрое меньше влияние состава лесообразующих пород, увлажнения и продуктивности, в 5 раз - антропогенного воздействия. Еще менее значим рельеф (8 \%) и провинциальные отличия $(0.2 \%)$. Во второй половине лета общий характер пространственной организации остается тем же, значимость макрозалесенности увеличивается на $17 \%$, что объясняется влиянием кочевок птиц. Поэтому во второй половине лета более резкие отличия связаны с доминирующим характером общей залесенности (55 \%), а не каждого урочища в отдельности. В группу менее значимых факторов вошли состав лесообразующих пород, продуктивность, рельеф, увлажнение и антропогенное влияние. Вероятно, это связано еще и с тем, что в конце 1970-х гг. расчет антропогенного влияния проводился без городских орнитокомплексов (Равкин, 1984). Кроме того, во всех известных исследованиях пространственная неоднородность населения птиц определяется в первую очередь облесенностью и составом лесообразующих пород деревьев (Равкин, 1984; Вартапетов, 1984, 1998; Цыбулин, 1999).

В наших исследованиях, как уже отмечалось, при значительном числе облесенных ландшафтных урочищ фактор облесенности - далеко не самый значимый, как и в техногенных ландшафтах Южного Прибайкалья. Наблюдается сельскохозяйственно-селитебная деградация естественных ландшафтов, которая становится определяющей. Поэтому настоящие лесные орнитокомплексы в антропогенно нарушенных 
островных и разреженных лесостепных лесах Западной Сибири не формируются. Облесенность и состав преобладающих древесных пород по значимости влияния уступают кормности, застроенности (в объединенном виде - макроурбанизации) и иным формам антропогенного влияния.

\section{ЗАКЛЮЧЕНИЕ}

Итак, во второй половине лета (в послегнездовой период) на территориальную неоднородность населения птиц Тоболо-Иртышской лесостепи и степи наиболее сильно влияют естественные факторы. Факторы антропогенного происхождения менее значимы для определения облика орнитокомплексов. Прежде всего, это макроурбанизация в виде искусственно повышенной кормности и озелененности городских и поселковых выделов и их застроенности. Известно, что крупные города давно уже приобрели орнитогеографическое значение в своих регионах (Ильичев, 1984), и наши расчеты подтверждают это. Так, существование крупного г. Омск и его пригородной зоны с населением более 1 млн чел. заметно увеличивает степень воздействия антропогенных факторов на формирование орнитокомплексов. Те же основные факторы ранее выделены для объяснения пространственной неоднородности орнитокомплексов слабо нарушенных участков лесостепи Западной и Средней Сибири (Жуков и др., 1985; Торопов и др., 1985; Жуков, $2006)$ и в лесной зоне Западной Сибири (Равкин, 1984; Вартапетов 1984, 1998). Всеми перечисленными факторами и их сочетаниями (природными режимами) во второй половине лета объясняется 58 \% дисперсии населения птиц.

Таким образом, при сравнении оценок силы и общности связи факторов среды с неоднородностью населения птиц менее нарушенных территорий лесной зоны Западной и Средней Сибири (Равкин, 1984; Вартапетов, 1998), а также лесостепи Приобья (Торопов и др., 1985) в ТоболоИртышской лесостепи и степи Западной Сибири и Северного Казахстана отмечено преобладание естественных факторов над антропогенными. Для формирования летних орнитокомплексов в гнездовой период антропогенные факторы становятся менее значимыми, чем природные, но более существенными, чем в остальных сравниваемых регионах Западной и Средней Сибири, за исключением лесостепи последней.

\section{ЛИТЕРАТУРА}

Берг Л. С. Природа СССР. Москва : Учпедгиз, 1938. $311 \mathrm{c}$.

Bapmanemoв Л. Г. Птицы таежных междуречий Западной Сибири. Новосибирск : Наука, Сиб. отд-ние, 1984. $240 \mathrm{c}$.
Bapmanemoв Л. Г. Птицы северной тайги ЗападноСибирской равнины. Новосибирск : Наука, Сиб. отдние, 1998.327 с.

Гармаев Е. Ж., Намжилова Л. Г., Ананин А. А., Бешенцев $A$. Н. Разработка программы мониторинга биоразнообразия на особо охраняемых природных территориях в бассейне озера Байкал // География и природные ресурсы. 2016. № 5. С. 247-254.

Жуков В. С. Пространственная структура и организация летнего населения птиц лесостепи Назаровской котловины (Средняя Сибирь) // Сибирский экологический журнал. 1997. № 6. С. 645-654.

Жуков В. С. Птицы лесостепи Средней Сибири // Новосибирск : Наука, 2006. 492 с.

Жуков В. С., Блинов В. Н., Вартапетов Л. Г., Торопов К. В., Цыбулин С. М. Пространственная структура населения птиц (северная лесостепь Западной и Средней Сибири) // Пространственно-временная динамика животного населения (птицы и мелкие млекопитающие). Новосибирск : Наука, Сиб. отд-ние, 1985. С. 56-67.

Ильичев В. Д. Управление поведением птиц. Москва : Наука, 1984. 303 с.

Павлов А. В., Гравис Г. Ф. Вечная мерзлота и современный климат // Природа. 2000. № 4. С. 10-18.

Равкин Ю. С. Пространственная организация населения птиц лесной зоны (Западная и Средняя Сибирь). Новосибирск : Наука, Сиб. отд-ние, 1984. 264 с.

Равкин Ю. С. Птицы лесной зоны Приобья. Новосибирск : Наука, Сиб. отд-ние, 1978. 288 с.

Равкин Ю. С., Ливанов С. Г. Факторная зоогеография: принципы, методы и теоретические представления. Новосибирск : Наука, 2008. 205 с.

Равкин Ю. С., Вартапетов Л. Г., Колосова Е. Н., Жуков В. С., Миловидов С. П., Торопов К. В., Цыбулин С. М., Юдкин В. А., Фомин Б. Н., Адам А. М., Покровская И. В., Ананин А. А., Пантелеев П. А., Блинов В. Н., Соловьев С. А., Вахрушев А. А., Равкин Е. С., Блинова Т. К., Шор Е. Л., Полушкин Д. М., Козленко А. Б., Ануфриев В. М., Тертицикий Г. М. Видовое разнообразие птиц Западно-Сибирской равнины и общие особенности их летнего распределения // Сибирский экологический журнал. 1994. № 6. С. 521-535.

Саловаров В. О., Кузнецова Д. В. Птицы техногенных ландшафтов Южного Прибайкалья. Иркутск : Изд-во Иркут. гос. ун-та, 2005. 346 с.

Соловьев С. А. Птицы Тоболо-Иртышской лесостепи и степи: Западная Сибирь и Северный Казахстан : в 2-х т. Т. 1. Пространственная структура и организация населения. Новосибирск : Изд-во СО РАН, 2012. 294 с.

Соловьев С. А., Вартапетов Л. Г. Экологогеографический анализ населения птиц ТоболоИртышской лесостепи и степи Западной Сибири и Северного Казахстана в первой половине лета // Сибирский экологический журнал. 2021. № 5. С. 613-622.

Степанян Л. С. Конспект орнитологической фауны России и сопредельных территорий в границах СССР как исторической области. Москва : ИКЦ «Академкнига», 2003. 808 с.

Торопов К. В., Фомин Б. Н., Козлов Н. А., Цыбулин С. М., Bартапетов Л. Г., Блинов В. Н., Жуков В. С. Пространственная структура населения птиц (лесостепь Обь-Иртышского междуречья и долины Оби) // 
Пространственно-временная динамика животного населения (птицы и мелкие млекопитающие). Новосибирск : Наука, Сиб. отд-ние, 1985. С. 67-79.

Цыбулин С. М. Птицы Северного Алтая. Новосибирск : Наука, Сиб. предприятие РАН, 1999. 519 с.

Gregory R. D. Development of breeding bird monitoring in the United Kingdom and adopting its principles elsewhere // The Ring. 2000. Vol. 22. P. 35-44.

Gregory R. D., Vorisek P., Strien A. Van, Meyling W. G., Jiguet F., Fornasari L., Reif J., Chylarecki P., Bur- field I. J. Population trends of widespread woodland birds in Europe // Biological Conservation. 2007. Vol. 149. P. 78-97.

Sanderson F. J., Donald P. F., Paln D. J., Burfield I. J., van Bommel F. P. Long-term population declines in AfroPalearctic migrant birds // Biological Conservation. 2006. Vol. 131. P. 93-105.

Svensson S. E. European bird monitoring: geographical scales and sampling strategies // The Ring. 2000. Vol. 22. P. 3-23.

\title{
SPATIAL-TYPOLOGICAL STRUCTURE AND ORGANIZATION OF ORNITHOCOMPLEXES IN THE TOBOL-IRTYSH FOREST-STEPPE AND THE STEPPE OF WESTERN SIBERIA AND NOTHERN KAZAKHSTAN IN THE SECOND HALF OF SUMMER
}

\author{
S. A. Soloviev, L. G. Vartapetov \\ Institute of Systematics and Ecology of Animals, SB RAS, Novosibirsk
}

\begin{abstract}
According to the results of bird counts carried out in 138 habitats over 12 years, a hierarchical classification and a structural graph of the similarity of ornithocomplexes in the plain southwestern part of Western Siberia and Northern Kazakhstan have been compiled in the period from 1982 till 2002. The hierarchical classification contains six types of bird populations. The similarity graph is built at the level of types and is represented by three rows (trends). One row consists of bird complexes of residential and recreational areas; the second, of wetlands; and the third, of forest, forest-field, and steppe habitats. The classification taxa characteristics contain information on the three most numerous bird species (leaders in abundance), their share in the community, population density, and the background species wealth. Based on the assessment of the similarity coincidence degree for the of bird communities and environmental factors, a hierarchy of the impact of the main anthropogenic and natural factors, determining the bird population formation, has been established.
\end{abstract}

Keywords: birds, ornithocomplexes, cluster analysis, environmental factors, correlation

\section{REFERENCES}

Berg, L. S., 1938. Nature of the USSR. Moscow, Uchpedgiz [In Russian].

Garmayev, E. Zh., Namzhilova, L. G., Ananin, A. A., Beshentsev, A. N., 2016. Developing the Program of Biodiversity Monitoring in Specially Protected Natural Areas of the Lake Baikal Basin, Geography and Natural Resources. 5, 247-254 [In Russian].

Gregory, R. D., 2000. Development of Breeding Bird Monitoring in the United Kingdom and Adopting Its Principles Elsewhere, The Ring. 22, 35-44.

Gregory, R. D., Vorisek, P., Strien, A.Van, Meyling, W. G., Jiguet, F., Fornasari, L., Reif, J., Chylarecki, P., Burfield, I. J., 2007. Population Trends of Widespread Woodland Birds in Europe, Biological Conservation. 149, 78-97.

Ilyichyov, V. D., 1984. Bird Behavior Management. Moscow, Nauka [In Russian].

Pavlov, A. V., Gravis, G. F., 2000. Permafrost and the Modern Climate, Priroda. 4, 10-18 [In Russian].
Ravkin, Yu. S., 1978. Birds of the Ob Forest Zone. Novosibirsk, Nauka [In Russian].

Ravkin, Yu. S., 1984. Spatial Organization of the Bird Population in the Forest Zone (Western and Central Siberia). Novosibirsk, Nauka [In Russian].

Ravkin, Yu. S., Vartapetov, L. G., Kolosova, E. N., Zhukov, V. S., Milovidov, S. P., Toropov, K. V., Tsybulin, S. M., Yudkin, V. A., Fomin, B. N., Adam, A. M., Pokrovskaya, I. V. Ananin, A. A., Panteleyev, P. A., Blinov, V. N., Soloviev, S. A., Vakhrushev, A. A., Ravkin, E. S., Blinova, T. K., Shor, E. L., Polushkin, D. M., Kozlenko, A. B., Anufriyev, V. M., Tertitsky, G. M., 1994. Species Diversity of Birds in the West Siberian Plain and General Features of Their Summer Distribution, Siberian Ecological Journal. 6, 521-535 [In Russian].

Ravkin, Yu. S., Livanov, S. G., 2008. Factorial Zoogeography: Principles, Methods, and Theoretical Concepts. Novosibirsk, Nauka [In Russian]. 
Salovarov, V. O., Kuznetsova, D. V., 2005. Birds of Technogenic Landscapes of the Southern Baikal Region. Irkutsk, Irkutsk State University [In Russian].

Sanderson, F. J., Donald, P. F., Paln, D. J., Burfield, I. J., Bommel, F. P. van, 2006. Long-Term Population Declines in Afro-Palearctic Migrant Birds, Biological Conservation. 131, 93-105.

Soloviev, S. A., 2012. Birds of the Tobol-Irtysh ForestSteppe and Steppe: Western Siberia and Northern Kazakhstan [In 2 Vols.]. Vol. 1. Spatial Structure and Organization of the Population. Novosibirsk, SB RAS [In Russian].

Soloviev, S. A., Vartapetov, L. G., 2021. Ecological and Geographical Analysis of the Bird Population of the Tobol-Irtysh Forest-Steppe and the Steppe in Western Siberia and Northern Kazakhstan in the First Half of Summer, Siberian Ecological Journal. 5, 613-622 [In Russian].

Stepanyan, L. S., 2003. Abstract of the Ornithological Fauna of Russia and the Adjacent Territories within the Borders of the USSR as a Historical Region. Moscow, Akademkniga [In Russian].

Svensson, S. E., 2000. European Bird Monitoring: Geographical Scales and Sampling Strategies, The Ring. 22, 3-23.

Toropov, K. V., Fomin, B. N., Kozlov, N. A., Tsybulin, S. M., Vartapetov, L. G., Blinov, V. N., Zhukov, V. S., 1985.
Spatial Structure of the Ornithocomplexes (Forest-Steppe of the Ob-Irtysh Interfluve and the Ob Valley), SpatialTemporal Dynamics of the Animal Population (Birds and Small Mammals). Novosibirsk, Nauka, Sib. Department. S. 67-79 [In Russian].

Tsybulin, S. M., 1999. Birds of the Northern Altai. Novosibirsk, Nauka [In Russian].

Vartapetov, L. G., 1984. Birds of the Taiga Interfluves in Western Siberia. Novosibirsk, Nauka [In Russian].

Vartapetov, L. G., 1998. Birds of the Northern Taiga in the West Siberian Plain. Novosibirsk, Nauka [In Russian].

Zhukov, V. S., 1997. Spatial Structure and Organization of the Summer Bird Population in the ForestSteppe of the Nazarovskaya Depression (Central Siberia), Siberian Ecological Journal. 6, 645-654 [In Russian].

Zhukov, V. S., 2006. Birds of Central Siberia's ForestSteppe. Novosibirsk, Nauka [In Russian].

Zhukov, V. S., Blinov, V. N., Vartapetov, L. G., Toropov, K. V., Tsybulin, S. M., 1985. Spatial Structure of the Bird Population (Northern Forest-Steppe of Western and Central Siberia), Spatial-Temporal Dynamics of the Animal Population (Birds and Small Mammals). Novosibirsk, Nauka. 56-67 [In Russian]. 